\title{
El murmullo de Dios en el murmullo del mundo. Notas para un diálogo interdisciplinar entre teología y literatura ${ }^{1}$
}

\author{
Patricio Lizama \\ FACULTAD DE LETRAS \\ PONTIFICIA UNIVERSIDAD CATÓLICA DE CHILE \\ Alberto Toutin \\ FACULTAD DE TEOLOGÍA \\ PONTIFICIA UNIVERSIDAD CATÓLICA DE CHILE
}

\section{Introducción}

El tema que nos convoca en este seminario interno es la pregunta por la realidad: ¿Qué es la realidad? ¿Qué conocemos de ella? ¿Cómo la podemos aprehender? ¿Qué es lo que podemos comunicar de ella en nuestros discursos? Estas preguntas tienen para nosotros, entre otros, un alcance teológico y metodológico. Teológico pues el discurso sobre el Dios manifestado en Jesús tiene la pretensión de presentarlo como fundante y decisivo para la comprensión, sentido y efectuación de la realidad ${ }^{2}$. Y metodológico, pues la complejidad de la realidad, del Dios que allí se manifiesta y actúa, por un lado, y el carácter insoslayablemente parcial y hermenéuticamente situado del discurso teológico, por otro, exigen a quienes practicamos la teología una aproximación que sea a la vez consciente de sus aportes y límites y principialmente interdisciplinar. Ningún discurso puede pretender decir el conjunto de la realidad, en sus distintos niveles. Al contrario, cada discurso desde su parcialidad modesta está abierto a las miradas y niveles de realidad que otros discursos aportan.

1 Este artículo fue leído el 29 de septiembre del 2009 en el seminario interno de profesores de la Facultad de Teología de la Pontificia Universidad Católica de Chile. El tema de este seminario fue: Hacia un diálogo interdisciplinario en el horizonte de la realidad.

2 Cf. Benedicto XVI, «Discurso inaugural de la V ${ }^{a}$ Conferencia de Aparecida (13 de mayo 2007)» en $V^{a}$ Conferencia General del Episcopado latinoamericano y del Caribe. Aparecida. Documento conclusivo (CEP-Chile, Santiago 2007), 12. 
En un intento de hacernos cargo de las preguntas antes señaladas y de las exigencias que ellas conllevan, un profesor de literatura, Patricio Lizama, y otro de teología, Alberto Toutin, nos hemos reunido para pensar y poner por escrito este trabajo. Se trata de un texto conjunto, elaborado como una pieza de piano a cuatro manos, fruto de varios encuentros y ricos intercambios en vistas de definir cómo íbamos a abordar el tema, cuáles iban a ser nuestras ópticas y nuestras referencias, y de qué manera las íbamos a articular en un discurso común que hiciera justicia a la vez a la aproximación literaria y a la aproximación teológica de la complejidad de lo real.

\section{Literatura y su modo de acceso a lo real}

La literatura, en sus diferentes formas de expresión (narrativas, dramatúrgicas y líricas, por señalar los géneros clásicos), ofrece un acceso mediato a la realidad. Dicho acceso se realiza a través de las creaciones de ficción, es decir, mediante una recreación imaginativa de lo real que es plasmada y modelada en formas literarias. Estas formas literarias, como toda producción humana, es histórica; hablan tanto de sus autores -su visión de mundo, su sensibilidad, su historia, etc., como de la época en que se elaboraron- aun cuando se hable de un emperador romano del siglo II o de un fabricante de perfumes del siglo XVII. Sin embargo, las obras literarias -y podemos decirlo de toda producción artística- no se explican totalmente y no se agotan en su sentido por el conocimiento de sus autores y de su contexto de elaboración. En el mundo ficcional que recrean, las obras artístico-literarias conllevan un plus de sentido y de realidad que obedece a un secreto y profundo impulso de sus creadores. El que haya creación estética constituye ya de alguna manera una toma de posición por parte del artista ante el hecho de encontrarse allí, en un mundo ya creado que lo recibe y que lo moldea. La creación artística, por audaz y transgresora que sea, es pues un momento segundo al enigmático hecho de encontrarse ya -arrojados o situados- en un mundo, de ser en lugar de no ser, de la existencia misma del ser y no la nada. Y la creación artística responde a este hecho con otra creación, no ex nibilo sino ex mundo. Toda obra de arte busca hacerse cargo, de alguna manera, de la enigmática condición e identidad humanas. De ello habla George Steiner cuando escribe: «El núcleo de la identidad humana es nada más y nada menos que la caprichosa aprehensión de la presencia y facticidad radicalmente inexplicables y de la perceptible substancialidad de lo creado: esto es: nosotros somos. Es 
la rudimentaria gramática de lo insondable» ${ }^{3}$. Pero la creación artística y particularmente la recreación ficcional del mundo no obedecen simplemente a la situación enigmática de encontrarse ya en un mundo creado, sino también a una toma de decisión frente a ella; una insatisfacción y una rebeldía ante sus horrores, injusticias y sin sentido, o el padecimiento de alguna forma de separación. Respecto de lo primero, el conocido escritor peruano Mario Vargas Llosa (1936) responde a la pregunta que un joven escritor -alter ego ficcional del autor- le hace sobre el origen de su disposición precoz a inventar personajes e historias:

«Yo creo que la respuesta es la rebelión. Yo estoy convencido de que aquel que se entrega a la creación de otras vidas diferentes de aquella que él vive expresa así de manera indirecta su rechazo y su crítica de la vida tal como es, del mundo real, y, al mismo tiempo, su deseo de remplazarla por esos mundos que él inventa gracias a su imaginación y a sus deseos» ${ }^{4}$.

Sobre la separación padecida como origen de la creación literaria y artística apunta con lucidez la escritora francesa Simone de Beauvoir (19081986): «Cada escritor ha sido llevado a la literatura por caminos distintos, pero pienso que ninguno escribiría si no hubiese sufrido, de una u otra manera, la separación, y si no buscase, de una manera o de otra, el modo de anularla» ${ }^{5}$. La literatura se crea así en el espacio de la obra, un lugar privilegiado para la intersubjetividad, el restablecimiento de una comunión perdida y anhelada.

Ahora bien, lo que los creadores expresan en sus obras requiere de lectores o espectadores que actualicen y concreticen las posibilidades de sentido contenidas en la obras. El proceso mismo de creación artística culmina en ellos. Para que eso sea así es necesario primero asumir el pacto que establece la obra de ficción con el lector mediante el cual éste suspende su juicio de realidad y acepta como real aquello que se presenta en la obra: un principito de otro planeta que cae en el desierto, una mujer amortajada que evoca su vida ante los deudos que la vienen a llorar, o un hombre que a fuerza de contemplar un pez en un acuario se convierte en uno de ellos. Y luego, el lector, enriquecido en su sensibilidad y transfor-

3 G. STEIner, Real Presences (The University of Chicago Press, Chicago 1999), 201.

4 M.Vargas Llosa, Cartas a un joven novelista (Ariel/Planeta, Barcelona 1997), 11-12.

5 S. DE BeAuvorr, ¿Qué es la literatura? (Losada, Buenos Aires 1967), 80. 
mado en su visión de mundo, aplica en su propio mundo las posibilidades de realidad que ha descubierto en la obra.

Para entrar experiencialmente en este modo de percibir lo real vemos una escena de uno de los Sueños (1990) del director cine japonés, Akiro Kurosawa (1910-1998). Un espectador pasa ante un cuadro de Vincent van Gogh en donde hay unas lavanderas, y luego, subyugado por esta imagen vuelve y se detiene ante él. Sin transición, el visitante del museo, y el espectador de la película junto con él, cruzan un puente y aparecen dentro de la escena, dialogando con las lavanderas y preguntándoles si han visto al señor van Gogh y dónde le puede ubicar. Buscándolo, lo encuentra en una plantación de trigo, bajo un sol radiante. Tras un breve diálogo que rezuma la intensidad de vida del pintor, éste se pierde caminando en medio del plantío. El espectador se pone entonces a su siga y va pasando cuadro tras cuadro, con la ilusión de poder reencontrarlo. El pintor desaparece. Sólo se le encuentra perviviendo en su obra. Y finalmente, el espectador aparece de vuelta en su mundo, contemplado ahora en una pintura el vuelo de unos cuervos, imagen de la muerte, y de hecho, último cuadro pintado por van Gogh.

Este sueño describe los caminos que ofrece la mediación artística (fílmica o literaria) de apertura y descubrimiento de la realidad. El acceso que ofrece no es inmediato sino a través de la obra misma. La obra tiene un formato definido, es modesta y limitada, lleva en sí las huellas de su época y de su autor. En el fondo, la obra es una mimesis o imitación creativa en lenguaje. No es la realidad misma sino más bien dicha realidad transfigurada por las posibilidades de expresión del lenguaje literario/fílmico y por la sensibilidad del creador. Para adentrarse en ella es necesario aceptar el pacto de realidad que ella propone. Se trata de ver esta obra como si fuera la realidad, suspendiendo momentáneamente el juicio sobre su adecuación de los descrito y/o pintado con lo real. Si bien la obra habla de la sensibilidad y de la visión de mundo de su autor, el espectador ha de renunciar a buscar, como clave de lectura de la misma, la intención querida por el autor. En el Sueño lo único que encuentra el espectador son otras obras del pintor. No hay posibilidad de acceder de nuevo al pintor sino a través de su obra, de sus colores, y a través de ella, de su forma particular de ver y de transformar la realidad. El movimiento interpretativo culmina cuando el espectador y/o lector vuelve a su mundo, enriquecido por la travesía hecha por la obra y dispuesto a desplegar las posibilidades de sentido descubiertas, en las circunstancias que son las suyas. De este modo, la obra de 
arte muestra su pretensión a la verdad, la que no se encuentra en la mera obra ni en la pura subjetividad del espectador o del lector, sino en el diálogo-puente que se establece entre la visión y experiencia de mundo, vehiculada en la obra, y la visión y experiencia de mundo del lector. Gracias a este diálogo, la obra puede abrirse a una plenitud de sentido, desde las condiciones concretas y limitadas de su creación a las condiciones siempre nuevas y cambiantes de quienes las aprecian y concluyen. Desde este punto de vista, toda obra artística es una «obra abierta» (Umberto Eco).

Esta descripción del acceso a lo real de la literatura queremos verlo en una efectuación concreta. Tomamos dos de los capítulos del libro Un año (1935) del escritor chileno Juan Emar (1893-1964) . Los capítulos escogidos corresponden a las anotaciones que hace el narrador en su anuario, tomadas durante los meses de abril y de agosto.

\section{La obra de Juan Emar, Un año. Una aproximación contextualizada al proceso de creación y de visión literaria de la realidad.}

Señalemos algunos aspectos del contexto general del artista, en este caso, el escritor Juan Emar, en la modernidad y especialmente de la periferia como lugar desde donde ve y aprecia el mundo.

\subsection{El artista en la modernidad}

El pintor de la modernidad descrito por Baudelaire se enfrenta a una realidad dinámica siempre en continuo movimiento. Ésta se manifiesta en la metrópolis, entendida como laberinto de relaciones sociales, espacio donde habita la multitud y lugar donde se verifican las interacciones transitorias, fugaces y fortuitas.

El artista allí debe captar el momento efímero y contingente. Su desafío es instalarse en medio de lo fugitivo y de lo infinito, colocar su visión y su energía sobre lo pasajero para percibir lo eterno en lo transitorio del presente que pasa. Él aprehende los «fragmentos fortuitos de la realidad», una «instantánea» de los seres humanos en la corriente de la vida social moderna, la cual contiene, dentro de sí misma, la posibilidad de revelar «el significado del mundo como totalidad».

El creador se convierte así en un «caleidoscopio dotado de conciencia» que, en medio o bien oculto del mundo, en la plaza o en la torre, recoge

6 J. Emar, Un año (Tajamar, Santiago 2008). 
la multiplicidad de la vida, la rápida y continua alternancia de impresiones externas e internas, la apretada sucesión de imágenes cambiantes, la brusca diversificación en el interior del plano que se capta, el carácter inesperado de las impresiones. Lo anterior revela la intensificación de la vida psíquica y una nueva percepción sensorial que se aleja del recogimiento, el abandono y la contemplación ante lo expuesto, y propone una percepción mediada por la técnica vinculada al carácter fragmentario, al shock producido por el cambio veloz de las imágenes, a la dispersión.

\subsection{La periferia latinoamericana: lugar de apropiación de la modernidad}

La sociedad moderna desarrolla una aguda conciencia sobre sí misma en un entorno desencantado, de creciente complejidad y cambio. Aunque exista una matriz común, no hay una «única vivencia prototípica de la modernidad, situada por fuera y por encima de los límites de la geografía, el tiempo, la clase social y las culturas locales» ${ }^{7}$. Al contrario, encontramos una gran variedad de «modalidades espirituales, vitales, materiales... a través de las cuales los elementos de esa matriz se combinan y especifican» ${ }^{8}$. América Latina experimenta la modernidad desde una condición periférica y dialoga con las corrientes y los temas de la modernidad central, lo que origina una experiencia de heterogeneidad cultural que se constituye por vía de múltiples hibridaciones.

Desde el margen, lugar que permite irreverencias, versiones desviadas, falsificaciones y una recepción inquieta e insubordinada, el discurso ajeno se recodifica, apropia y se inserta en un nuevo contexto histórico y cultural donde se naturaliza y hace sentido. Esta manera de participar supone que la modernidad latinoamericana puede leerse como «expresión de una intertextualidad; es un producto de transferencias, citas, apropiaciones [...] y un gran y desordenado proceso de acumulación cultural a partir de medios precarios y ricas, complejas mediaciones»?

Al mismo tiempo, el continente se puede entender como un espacio de enunciación diferencial, como una periferia que asumiendo «las estructuras y los dispositivos de la desigual distribución del capital, el conoci-

J. J. Brunner, «Modernidad» en C. Altamirano (dir.), Términos críticos de sociología de la cultura (Paidós, Buenos Aires 2002), 176.

8 J. J. BRunNER, «Modernidad», 176.

9 J. J. Brunner, «Modernidad», 178. 
miento y las tecnologías ${ }^{10}$, construye una modernidad que sin renegar de lo propio incluye el discurso ajeno. Las sociedades modernas latinoamericanas, a partir de esta hibridación constitutiva, son sociedades multiculturales resultado de la sedimentación, yuxtaposición y entrecruzamiento de las «acciones políticas, educativas y comunicacionales modernas, de tradiciones indígenas [...] y del hispanismo colonial católico», lo que les da su perfil específico ${ }^{11}$.

\subsection{El artista y el acceso a lo real en la modernidad periférica. Los obstáculos}

En Un Año, los sucesos del primero de abril colocan al protagonista ante un presente que pasa, una imagen momentánea que él observa a través de la ventana de su casa: el cortejo fúnebre de un amigo. Si bien este «fragmento fortuito» ${ }^{12}$ constituye una experiencia de la modernidad, según se revelará al final del segmento, ésta se encuentra situada en una sociedad periférica lo que implica un desafío adicional para el personaje pues, además de tratar de captar el fragmento, debe desarticular los obstáculos que limitan su capacidad de percibirlo. El episodio resulta una alegoría del doble quehacer del artista en una modernidad periférica.

La marcha fúnebre anuncia el paso del cortejo y el narrador «se precipita como un loco a su encuentro». Pero no logra observar bien lo que ocurre en el exterior, "pues las ventanas de mi casa tienen, a la usanza colonial, gruesos barrotes de hierro» ${ }^{13}$. Distanciado de su objeto, pues no posee la perspectiva exterior de la calle, contempla desde un umbral y oculto para el mundo. Ahí, el observador del paisaje callejero, desde un margen, ve pasar a «grandes, enormes, imponentes, cosacos», «cada uno sobre un gigantesco caballo negro», los que por sus insólitas dimensiones, «cubrían los edificios de enfrente, cubrían el cielo» ${ }^{14}$.

La escena muestra una visión del paisaje urbano que está mediada por dos grandes dificultades. La primera son los barrotes coloniales, sinécdoque de la pervivencia de lo pre-moderno y sus inamovibles tradiciones, de

\footnotetext{
10 J. J. BRunNER, «Modernidad», 177.

11 N: García Canclini, «¿Modernismo sin modernización?», Revista de Sociología (México) 3 (1989), 172.

12 Cf. D. Frisby. Fragmentos de la modernidad: teorías de la modernidad en la obra de Simmel, Kracauer y Benjamin (Visor, Madrid 1992).

13 J. EMar, Un año, 29.

14 J. EMAR, Un año, 32.
} 
la sociedad tradicional dominada por el hispanismo colonial católico, la cual, a través de la constelación de elite y los mecanismos y aparatos de su institucionalidad, coarta la diseminación de la modernidad e impide el florecimiento de nuevas subjetividades. La ventana, en vez de facilitar el acceso al conocimiento de realidades emergentes, encarcela al artista tras los barrotes, restringe su campo visual, su libertad de movimiento y le impide explorar más allá del territorio adjudicado. La ventana es una apertura, pero que impide salir a lo abierto, a «la gran totalidad de todo aquello que no tiene límite», es una cifra de la sociedad que enclaustra al creador y le coarta sus capacidades intelectivas y perceptivas.

La segunda dificultad son los cosacos y los caballos, sinécdoque del poder militar y de la dictadura de Carlos Ibáñez, la cual se inicia en 1927 y culmina con su renuncia en $1931^{15}$. En términos culturales, este gobierno concibe el sistema identitario como orgánicamente cerrado y reivindica la pureza de lo vernacular frente a una modernidad extranjera que negaría lo propio. Con esta perspectiva, el arte tiene como tarea ideológica la articulación de una identidad nacional basada en una esencia inconmovible, cuyas raíces se hallan en los antepasados indígenas, de modo que el ibañismo sostiene la necesidad de «enderezar todos los cauces de la belleza», lo que implica terminar con la imitación de modelos foráneos. Si el carácter nacionalista promovido por el Estado impregna al conjunto de las artes, la autonomía del campo cultural se debilita y las propuestas vanguardistas son excluidas y rechazadas con gran celo. Como la representación en algunos cuadros de Magritte, el gobierno de Ibáñez eclipsa la modernidad artístico-cultural.

Las dos mediaciones que se interponen entre el protagonista y el paisaje urbano lo obligan a asumir la tarea de desmontar el orden colonial -iglesia, ejército- y desactivar el poder de ocultamiento del gobierno dictatorial. Esta labor de resistencia, porque allí donde hay tecnología de sujeción, también está «aquello que resiste, altera, muta esos regímenes normativos $»^{16}$, el narrador la realiza a través del lenguaje, pues la desmesura inicial de caballos y cosacos sustentada en la reiteración y gradación, la

15 El gobernante es doblemente aludido en esta escena: por su sobrenombre, el caballo, y por su calidad de militar. Agreguemos que el gobierno de Ibáñez presionó y amenazó al padre de Emar, Eliodoro Yáñez, quien en 1927 se vio obligado a venderle La Nación, el diario de su propiedad, a un precio irrisorio.

16 G. Giorgi - F. Rodríguez (dirs), Ensayos sobre biopolítica; excesos de vida (Paidós, Buenos Aires 2007), 11. 
hipérbole y los epítetos - grandes, enormes, imponentes, gigantescos- desaparece con el uso del oxímoron, las comparaciones y los diminutivos. Así, el último cosaco de gran estatura y el "gigantesco caballo negro», al alejarse, devienen "grande como un ratón», la carroza es chiquita y los deudos «iban ahí como hormigas, como hormiguitas ...titas» ${ }^{17}$.

$\mathrm{Al}$ deshacer los obstáculos, el narrador puede acceder a una visión más completa de la calle: «Se veía el cielo. Ya aparecían los edificios en las proporciones de enfrente. Ya se veían enteros $»^{18}$. Los efectos derivados de este cambio son múltiples. La desarticulación final del lenguaje indica el resquebrajamiento de los grupos dominantes y de las fuerzas retardatarias, de sus poderes y sus restricciones: todos ellos son rebajados y desalojados de la escena. El cortejo fúnebre se convierte en alegoría y sátira de la muerte de la sociedad tradicional y del gobierno ibañista. El paisaje que se hace visible consagra el triunfo de la posición del protagonista que estaba en el margen: quien mira, a través de saberes y prácticas, logra desocultar la modernidad; si al comienzo del episodio él mira hacia la calle, pero queda pegado a los barrotes coloniales «como un insecto en el radiador de un auto veloz», indicio kafkiano de la alienación y exclusión del artista en la modernidad, al final del episodio se engrandece ya que logra expandir su visión.

La escena revela a cabalidad la experiencia del artista en la modernidad periférica. El vive un extrañamiento respecto al espacio que habita lo cual sensibiliza su autonomía y su sentido crítico; es un extranjero que mantiene una relación de proximidad y distancia respecto a la sociedad que observa. A la vez, define de modo cabal el concepto emariano de arte: «¿Qué es el arte sino un estallido? ¿Qué puede ser sino un perpetuo descalabozamiento?».

\subsection{El artista y las mediaciones. La «dura y delicada tarea» de escribir}

El protagonista lee un periódico de cuyas páginas se desprende un «ligero murmullo universal», que si bien informa acerca de lo que ocurre, está mediado por la naturaleza de la comunicación periodística y por un lenguaje que tiende a expresar una significación unívoca, reitera construcciones establecidas, es portador de visiones y juicios cristalizados, utiliza significados compartidos y configura un discurso normalizador.

\footnotetext{
17 J. EMar, Un año, 30.

18 J. EMAr, Un año, 32.
} 
Al caer las letras de la página, se revela el vaciamiento de la referencialidad y el personaje se enfrenta a la página en blanco la cual suscita la tarea del escritor: percibir y recrear el mundo, transfigurarlo y comunicar un nuevo «murmullo universal» a partir de una verdadera danza de significantes que él teje de otra forma.

La escena pone de relieve la conciencia metaliteraria que tiene el escritor acerca del filtro con que interpreta y desea expresar su visión, porque toda obra tiene un advenimiento en el lenguaje. Él asume que las palabras están enclaustradas en significaciones que ocultan y falsean la realidad de modo que necesita desarraigarlas, arrancarlas de sus conexiones y significados habituales, pues cada una de ellas está unida a una serie de significaciones veladas, a asociaciones en la oscuridad de la conciencia, a una connotación afectiva, moral, política, que siempre está cargada de valoraciones, voces y acentos opuestos, porque todo acto verbal se instala en cadenas previas de enunciados y nunca lo hace en forma neutra ${ }^{19}$.

Una vez despojadas las palabras de esa carga ideológica y desde la identidad material de la lengua y de los géneros discursivos que elige, el escritor, con una mirada inaugural para la cual el mundo es siempre algo nuevo, un hoy virgen y bello, como decía Mallarmé, elabora un lenguaje de carácter ambiguo y autorreflexivo que con diferentes connotaciones y renovadas marcas ideológicas, modifica las valoraciones hegemónicas y cristalizadas, porque posee una riqueza derivada de un sentido múltiple -significando una cosa, al mismo tiempo significa otra sin dejar de significar la primera- que permite al lector enfrentarse a una polisemia.

El artista, a través de una escritura que deviene estrategia de desfiguración y anomalía contra las producciones normativas, crea un mundo nuevo que enriquece y prolonga nuestra vida porque éste hunde sus raíces en la experiencia humana y tiene siempre como referente último a la realidad: pensada, soñada, imaginada, combatida, sufrida, porque las formas de la experiencia humana son innumerables. De allí la insoslayable dimensión ética, social, política, moral, religiosa de toda literatura. Esta problemática la advertimos en este episodio emariano por cuanto el narrador se interroga acerca de qué intencionalidad darle a la escritura, disyuntiva que se plantea en tres planos complementarios: qué realidades comunicar, la

19 Cf. E. Drucaroff. Mijail Bajtín: la guerra de las culturas (Almagesto, Buenos Aires 1996). 
esfera de lo alto o de lo bajo; qué sujetos representar, el del poder o el del margen y cómo abordar todo ello, risa o seriedad.

\section{El profeta como vidente escritor. Una figura paradigmática de la práctica comuni- cativa teológica y literaria}

Al inicio del libro del profeta Ezequiel, encontramos el relato de su vocación $(2,8-3,3)$. El profeta aparece como un sujeto convocado por Dios, quien se dirige a él mediante palabras y visiones. Dios toma la iniciativa de llamarle para que comunique sus palabras a los israelitas, que se han mostrado tenazmente rebeldes a sus interpelaciones. Al mismo tiempo, Él empeña su palabra con el profeta animándole a no temer a las resistencias que encontrará en el cumplimiento su misión. De alguna manera, el profeta vivirá en carne propia la incomprensión que sufre Dios por la rebeldía que el pueblo manifiesta a sus llamados. El pathos de Dios se hará entonces presente en medio de ellos en la vida, las palabras y las visiones del profeta. Esta dinámica se desvela en la visión vocacional del profeta: Dios le ofrece un libro enrollado, escrito por ambos lados, que al desenrollarlo se ve el contenido que deberá anunciar: «Lamentaciones gemidos y ayes» (Ez 2,10). Además, este contenido debe ser asimilado por el profeta, comprometiendo su vida entera: las palabras de Dios se hacen carne y palabra en el profeta. Esto se expresa en la imagen del libro que el profeta debe comer. Aun cuando el contenido de las palabras que debe anunciar es contrariante y duro para el pueblo, sin embargo, en boca del profeta dichas palabras saben dulce como la miel. Extraño sabor de la misión del vidente profeta: amargura por las oposición que encontrarán las palabras que debe anunciar y dulzura por la cercanía tesonera de Dios, más fuerte que la rebeldía de Israel.

Guardando todas las proporciones, en este relato se presentan los elementos esenciales de la tarea teológica y de la tarea literaria como práctica comunicativa. La iniciativa, la inspiración, el impulso inicial no vienen del mismo teólogo o del escritor, sino de una palabra que le precede, que le interpela y lo llama, de una visita inesperada. Todo discurso teológico es eco, palabra segunda sobre el Dios que habla (Théos legôn) y actúa primero. El escritor literario siente la necesidad de escribir, hay algo que se le impone y que lo lleva a escribir. Esta iniciativa o inspiración - divina o artística- se manifiesta apelando a todos los recursos del espíritu humano: visión, audición, palabras, imaginación e imaginario puestos en un contexto de diálogo entre él y el sujeto convocado. La palabra en la que 
Dios se autocomunica a los hombres, y en la que éstos la reciben como tal, es primeramente una palabra visual, contextualizada, metafórica, enraizada en el imaginario, en la sensibilidad, en la corporeidad -iLa palabra el profeta tiene que devorarla!- y que apela por cierto a la capacidad de discernimiento, de respuesta, de juicio y de decisión de sus interlocutores. Este diálogo además, en cuanto acción comunicativa, está situado en un momento histórico preciso y orientado primero hacia el mediador vidente y luego hacia el pueblo o destinatario que moldean el contenido de lo anunciado. Las palabras de Dios que anuncia el profeta son fruto de una triangulación comunicacional: Dios, que habla y actúa, el pueblo, destinatario y término de estas palabras, y la mediación del profeta, que en sus visiones, palabras y su vida misma, da cuerpo situado a esas palabras, tanto en su anuncio como en su recepción. La acción comunicacional de Dios mediada por el profeta o la del escritor no se limita a acoger la iniciativa soberana de Dios o el impulso incoercible de la inspiración, sino que requiere que dichas palabras sean asimiladas por el profeta mismo, por el autor literario y luego comunicadas al pueblo como visiones y palabras provenientes de Dios. En el caso del anuncio profético, éste tuvo un primer momento oral. Dicha dicción pervive en la forma de un escrito que recoge la iniciativa comunicante de Dios. Al mismo tiempo, ofrece a dicho acontecimiento una futuridad de sentido, en la medida en que Dios continúa comunicándose, en la ambigüedad y transitoriedad de la historia, como el que habla mediante visiones y palabras dirigidas a un pueblo que puede así desentrañar el sentido de su propio actuar a la luz del actuar de Dios.

\section{Algunas tareas que se siguen para el quehacer comunicativo de teólogos y literatos}

A la luz del recorrido que hemos hecho hasta aquí, queremos esbozar algunas tareas que se desprenden para el quehacer comunicativo de la teología y de la literatura en su apertura a lo real. Estas tareas las podemos sintetizar en tres acciones: escuchar, escribir, comunicar:

a) Atención al murmullo de Dios en el murmullo del mundo. Como veíamos en el relato de Juan Emar, la penosa y delicada tarea del escritor es escuchar, discernir y poner por escrito de manera razonada el «murmullo del mundo», ofrecer un sentido articulador al acontecer fugaz y efímero, lo que va tejiendo la trama de los días, que de otra 
manera permanecería insignificante y nosotros desengarzados de la historia que nos moldea y que posibilita o impide el que advengamos a los que estamos llamados a ser. La creatividad literaria, con toda la autonomía que pueda reivindicar para su propio quehacer, está vinculada a este murmullo: lo puede descifrar, parafrasear, parodiar, en todo caso reinventar, pero es siempre su punto de partida. La escucha del murmullo de la realidad que desarrolla el artista, supone concebirlo como alguien que, con una predisposición singular que transforma en destino, está entre porque se enfrenta a lo real para percibir y conocer lo visible y lo invisible que surge en los intersticios, en las fisuras del mundo de la apariencia. Ello significa que es un extrañado que vive siempre atento al paralelaje, que es sensible a la lateralidad y experimenta el «sentimiento de no estar del todo» en los escenarios de la vida porque se sitúa siempre en un umbral para esperar lo inesperado. El artista, aquel que contempla y crea para comprender, vive la experiencia del paso al mundo otro que puede surgir en cualquier circunstancia, sin aviso ni advertencias, como una experiencia radical, como una verdadera revelación. Él se traslada «tan así, tan resbalando», se enajena en el objeto - «con mi razón apenas, con mis dedos, /caigo en la sombra... y miro arañas, y apaciento bosques»- entiende la necesidad de cederse y de esa forma logra aprehender y ser eso mismo que canta. Como señala Keats: «Si un gorrión viene a mi ventana, participo de su existencia y picoteo las arenillas».

La teología, por su parte, en su acción comunicativa, ha de poner sus mejores recursos -los que están disponibles y los que ella misma forje- al servicio de escuchar y dejarse interpelar por el murmullo de Dios en el murmullo del mundo. En esta delicada y penosa tarea, la teología está llamada a participar y a hacer participar a otro de Aquel de quien habla. Su tarea se inscribe en ese vasto movimiento interpretativo de la fe que es la Tradición eclesial, no sólo en sus fuentes escritas, sino también en su realidad operante como son los sacramentos, los ministerios, el sensus fidei de los fieles. También ha de estar atenta a los signos de los tiempos, a los pobres, a la cultura, al arte como lugares en que Dios actualiza su presencia: manifiesta al modo de una epifanía su visita inesperada. Para hacer ese discernimiento la teología cuenta de manera privilegiada con la conversación que establece entre el presente, el hoy de la fe y la autocomunicación de Dios recogida en las Escrituras. Esta conversación requiere no sólo una razón racio- 
cinante sino también una razón dialógica e imaginativa, que se haga cargo de las imágenes, historias, situaciones, emociones y afectos que se encuentran implicados en los relatos bíblicos y en el murmullo del mundo. De hecho, el Dios manifestado en Jesús se ha expresado en primer lugar para decir que el sentido profundo de la historia, de su origen y de su fin, del mal, de la culpa, de la esperanza, ya se encuentra recogido en mitos y relatos fundacionales o teleológicos, los asume para ofrecer no sólo un nuevo sentido, sino también nuevas posibilidades inéditas de realidad. Esta forma de habitar y de transformar los imaginarios colectivos y textuales tiene que ver con el ser mismo de Dios, vuelto hacia nosotros, y con su modo de actuar, ofreciéndonos su vida como don. Ello es lo que expresa en palabras sugerentes Pie Duployé cuando describe la Biblia así:

«La Biblia es una historia y porque es una historia, es inagotable. Ella es el tipo de libro abierto. El Dios que nos revela es un Dios imprevisible, un Dios magnánimo, generoso, un Dios que se divierte, como Prâkriti de Claudel $^{20}$, un Dios a quien no le gusta la uniformidad y que en su criatura ignora el principio de 'todos por igual': Da más gracia a unos que a otros; un cierto desorden -aparente- no lo atemoriza. Nos enseña que una cierta imperfección formal es el signo de la vida; y cuando su obra ya está realizada, se da el tiempo para maravillarse. Dios es un artista y no un ingeniero. A una inteligencia racionalista, hay que hacerle entender en primer lugar que el Dios de la Biblia, en un cierto sentido, no explica nada sino que crea y profundiza un misterio que lo sitúa todo pero que no facilita una lectura lineal de las cosas» ${ }^{21}$.

b) La penosa y delicada tarea de escribir. El poeta que sale a lo abierto, al mundo de lo no formado ni conceptualizado, ve en la comunicación analógica con su circunstancia una facultad esencial y eficaz para aprehender relaciones, sentir los elementos del mundo próximos y conexos, y explorar un mundo irreductible a la razón. ¿Cómo se puede decir, comunicar esta experiencia para que lo dicho sea? Con un desarre-

20 Cf. P.Claudel, «La légende de Prâkriti» en Figures et Paraboles (Gallimard, Paris 1936), 103-159.

21 P. Duployé, «De la littérature d'imagination» en Jeux et poésie (Cerf, Paris 1944), 11, retomado once años más tarde en el libro del mismo autor, Rhétorique et Parole de Dieu (Cerf, Paris 1955), 28. 
glo de los sentidos, con lenguaje que fluye o converge, desarrimado. Por otra parte, la literatura se debe, por decir así, a sus destinatarios, punto culminante del proceso creativo, a quienes ofrece las posibilidades de sentido que ella despliega. Tanto el desciframiento del murmullo del mundo -lo que quiere darnos a entender de él- así como los destinatarios a los que se dirige -para quiénes escribe- y el modo en que procura hacerlo, corresponden a una opción no sólo estética sino social e incluso política. Con los significantes y con las palabras -que arrastran con ella una historia, que hablan de su valor, de su sentido- la literatura puede hablar de Su Alteza en su matrimonio o de La ramera que puso fin a sus días. En esta misma opción, la literatura puede explorar lo insondable de la realidad, no sólo mediante las palabras sino también mediante los silencios y los vacíos, y descubrir en esos intersticios la irrupción de una iniciativa imprevisible, que en teología podemos llamar Dios, no sólo en un viaje hacia lo alto y sublime (como en Alsino de Pedro Prado) sino también hacia lo bajo y las zonas oscuras de lo real (por ejemplo, Las flores del mal de Charles Baudelaire). Este llamado que la teología puede dirigir a la literatura se funda en que el Dios se hizo visible en la humanidad asumida por Jesucristo, Él es su imagen concreta y su exegeta, y nos ofrece, mediante su Espíritu, caminos para descifrar en el devenir humano, en la historia, la posibilidad de hacer experiencias inéditas de Dios.

La tarea de escritura, para el teólogo, surge del modo mismo como Dios quiso darse a conocer, en un diálogo, cuya palabra/acontecimiento es de Dios en la medida en que hay un interlocutor que la acoge como tal. Por decirlo de otra manera, la teología se sitúa en el espacio de sentido que se abre entre la proclamación eclesial de la Palabra de Dios en el hoy de una comunidad y la respuesta doxológica que esta comunidad ofrece a esta palabra, desde el hoy: Gloria a ti, Señor Jesús. Otra exigencia tiene que ver con los destinatarios de la teología. La literatura nos advierte que todo acto comunicacional de escritura es una opción que tiene también un alcance político: ¿Para quién ella escribe? ¿Qué aspectos del murmullo del mundo va a descifrar? En el campo teológico estas preguntas no son ajenas a su quehacer propio, a su reflexión sobre el murmullo de Dios en el mundo. De alguna manera, por mucho que su trabajo se haga en los cuidados espacios académicos, su quehacer no es ajeno a lo que pasa en la plaza pública, lo quiera o no, está inter-ferida por los acontecimientos y tensiones de nuestra 
situación social, política y eclesial. Y además, el lugar desde dónde se sitúan sus practicantes, los destinatarios para quiénes éstos escribe, les hace ver aspectos diferentes de Dios y de su murmullar en el mundo. No es el mismo Dios el que se reflexiona teniendo como interlocutor el mundo ilustrado indiferente a lo religioso que el mundo de los desfavorecidos, o el que se reflexiona desde la periferia del tercer mundo. De alguna manera, la literatura advierte a la teología que su acto de escribir dice a la vez de lo que se quiere mostrar y de para quiénes se lo quiere mostrar.

c) E1 estatuto revelante de las proposiciones literarias y teológicas. La literatura, mediante su recurso a la ficción, ofrece un camino de acceso a la verdad que supone el concurso de los lectores. Éstos, aceptando como real lo que se reconfigura en una obra y colaborando en las concreciones de sentido contenidas en ella, pueden hacer suyas las posibilidades de comprensión de sí y del mundo. El lector sale transformado por su travesía por la obra, en la medida en que ésta le revela aspectos inéditos de sí mismo y del mundo y lo enriquece en sus modos posibles de ser y de habitar el mundo. Es aquí donde la literatura hace la verdad que propone y verifica su pertinencia. La verdad de la literatura se ha de medir según el poder revelante del mundo y del ser humano en él: revelación no sólo de lo que es y se ve sino lo que podría ser, de los anhelos y de lo invisible que se muestra en los intersticios de la realidad.

De manera analógica, la teología, por su parte, reflexiona sobre un Dios cuyo ser y actuar se verifica en su capacidad de desvelar el sentido último de la historia, del ser humano. El modo como Dios se hace presente es del orden de una revelación de sí, en el corazón de los acontecimientos de la historia, de la reflexión sobre el sentido de la vida, de los estados de ánimo del orante hacia Dios, de la normativa que expresa la voluntad de Dios, de las visiones que sustentan la vocación profética, de las parábolas que hablan de la irrupción del actuar de Dios en el actuar de Jesús, etc. La teología no reflexiona sobre Dios en sí sino en su permanente volcarse hacia el ser humano, en cuyo movimiento Él mismo se desvela y a la vez revela su querer para la enigmática condición humana. Las proposiciones sobre el Dios que así se revela no pueden contentarse con mostrar dónde está sino 
también disponer a su acción transformadora. Hacemos nuestras las palabras con las que Adolphe Gesché, hablando de la experiencia del mal, ve a teólogos y literatos mancomunadamente trabajando y señala las connivencias y exigencias comunes que se les imponen a su quehacer discursivo y a su pretensión a la verdad: «A propósito del mal [...] creo que lo que se puede pensar o decir al respecto, es un poco como el escritor: lo que era un anuncio - 'Yo soy el adversario del mal' dice Dios-, crece o no, produce fruto o no, en la medida en que me libera, me desaprisiona, me ayuda a vivir. En el fondo, un criterio de justeza de una proposición teológica, de su adecuación a la realidad, es que sea revelante. Es 'revelado' si es 'revelante' (en el doble sentido que doy a la palabra 'Revelación'), si lo que pude escribir a propósito de Dios y del mal me abre y me libera, tal vez $»^{22}$.

d) Saber y legitimación. El intelectual, figura característica de la modernidad, es alguien dotado de un capital cultural que trabaja en el ámbito de la cultura o del poder, se especializa en el debate, y con una actitud de constante vigilancia y facultado para representar y articular un mensaje, hace públicas sus opiniones a través de aparatos de comunicación y/o formación, los cuales poseen diversas posiciones y distinto peso funcional en el campo. Desde esta perspectiva, la labor del intelectual adquiere la forma de un efecto comunicativo, pues desde un lugar de autoridad más o menos reconocida, comunica su pensamiento a través de los aparatos para persuadir ideológicamente y convertir su saber en influencia, desafío que lo lleva a desarrollar estrategias individuales y colectivas.

La universidad, institución relevante dentro del sistema de enseñanza y centro que forma a las elites intelectuales de la sociedad contemporánea, es un espacio donde se trabaja para la producción de la creencia, un lugar donde se busca legitimar el saber. Ello porque éste no se valoriza únicamente por sus contenidos intrínsecos, sino que necesita producirse, transmitirse, aceptarse, para luego sostenerse como tal. Los profesores son parte de los cuerpos especializados en la producción, circulación y consagración de las significaciones y los bienes simbólicos, y disputan por el monopolio de la producción cultural por medio

22 A. Gesché, «Entretiens avec Hector Bianciotti» en Les mots et les livres. Pensées pour penser II (Cerf, Paris 2004) ,142. 
de estrategias que dependen de la posición que cada actor, individual o colectivo, ocupa en el campo.

La pregunta acerca de la realidad y cómo acercarse a ella pasa entonces por lo que ha sido propuesto y legitimado como verdadero. Ello significa hacerse cargo del papel que el humanista desempeña en la universidad, de lo que realiza para convertir su saber en influencia, de las modalidades que emplea para valorar o desconocer un pensamiento. Hablar, escribir, elegir bibliografía; seleccionar profesores, organizar seminarios y coloquios; opinar en los medios, formar círculos de estudio, elaborar proyectos de investigación, entre otras cosas, son prácticas muy significativas en el orden del conocimiento y de su valor porque son manera de postular lo que se propone como verdad y en último término, de proponer lo que se desea que se considere como real. 
Resumen: El presente artículo es un trabajo realizado a cuatro manos entre un profesor de literatura y uno de teología que se abocan a la cuestión de su acceso y comprensión de lo real -murmullo del mundo-y de cómo reconocer allí el paso o la iniciativa imprevisible de Dios - murmullo de Dios. Esta auscultación de lo real lo hacemos en el espacio de la obra Un año (1935) del escritor chileno Juan Emar (1893-1964). Proponemos al final algunas notas para continuar este diálogo interdisciplinario entre teología y literatura.

Palabras clave: teología y literatura, investigación interdisciplinar, Juan Emar, lectura teológica de la realidad.

Abstract. The present article is a joint effort between a literature professor and a theology professor, who approach the question of accessing and comprehending reality -the murmur of the world - and of how to recognize in it the passing or unpredictable initiative of God -the murmur of God. We analyze this sounding out of reality using the novel Un Año (1935) by the Chilean writer Juan Emar (1893-1964). At the end, we make some suggestions toward continuing this interdisciplinary dialogue between theology and literature.

Keywords: theology and literature, interdisciplinary research, Juan Emar, theological reading of reality. 